\title{
LOCAL-CENTRAL INTERGOVERNMENTAL FISCAL RELATIONS OF CHINA
}

\author{
Yang Zhiyong \\ National Academy of Economic Strategy of Chinese Academy of Social Sciences (CASS), \\ Beijing, China
}

\begin{abstract}
For a large country like China, handling of intergovernmental fiscal relations must create compatible incentives to central and local governments. China initially created a fiscal management system characterized by tax sharing in 1994, basically meeting the needs of its socialist market economic system. Yet further improvements must be made to the assignment of administrative authority and expenditure responsibilities, revenue allocation and the fiscal transfer payment system. This paper is based on the author's previous research and the recent situation of adjustment in China's intergovernmental fiscal relations. The paper examines the problems of local-central fiscal relations: insufficient alignment between fiscal revenues and administrative authority; uncertainty of sharing the revenue from income tax and value-added tax; imperfect tax rebate and transfer payment system. Concludes that uncertainties of local fiscal resources inevitably affected the behavior of local governments. The paper describes the land sales revenues of local government as the example how the interplay intergovernmental fiscal relations with other systems threatens socio-economic sustainability of China. The following measures in tax reforming are suggested: increasing the share of local governments in VAT distribution; reducing the property tax rates; canceling tax rebates; endowing local governments with certain taxing authority, including legislation and tax rate adjustment. In handling intergovernmental fiscal relations, great attention must be paid to the system's stability to give play to its function of incentives and restraints
\end{abstract}

\section{KEYWORDS}

Fiscal management, intergovernmental fiscal relations, fiscal system, sharing tax revenue

\section{HIGHLIGHTS}

1. China must create a hierarchical fiscal management system in line with its modern fiscal system and further standardize the division between administrative authority and expenditure responsibilities

2. China should formalize a fiscal transfer payment system, and develop a hierarchical fiscal management system encompassing the sharing of tax, rents and profits

\section{ПРОБАЕМЫ МЕЖБЮАЖЕТНЫХ ОТНОШЕНИЙ ЦЕНТРААЬНОГО И МЕСТНОГО УРОВНЕЙ ВААСТИ В КИТАЕ}

\author{
Ян Чжиюн \\ Национальная академия экономической стратегии \\ Китайской академии социальных наук, г. Пекин, Китай
}

\begin{abstract}
АННОТАЦИЯ
Межбюджетные отношения в таких крупных странах как Китай должны быть разработаны таким образом, чтобы создавать совместимые стимулы для центральных и местных органов власти. Система фискального управления с распределением налогов, созданная в Китае в 1994 г., в основном удовлетворяла потребности социалистической рыночной экономической системы страны. Тем не менее, существует необходимость совершенствования административ-
\end{abstract}


ных полномочий и расходных обязательств различных уровней власти, а также внесения изменений в распределение доходов и систему межбюджетных трансфертов. Статья базируется на предыдущих исследованиях автора и учитывает недавнюю корректировку сферы межбюджетных отношений в Китае. В ней рассматриваются такие проблемы фискальных отношений между центральным и местным уровнями власти как недостаточное согласование между налоговыми поступлениями и административными полномочиями; неопределенность распределения доходов от подоходного налога и налога на добавленную стоимость; несовершенство налоговых скидок и межбюджетных трансфертов. Делается вывод, что неопределенность объема доходов местных бюджетов неизбежно влияет на поведение местных органов власти. На примере получения доходов от продажи земли местными органами власти показано, что проблемы межбюджетных отношений во взаимосвязи с другими системами угрожают социально-экономической устойчивости Китая. Предлагаются следующие направления налоговых реформ: увеличение доли налога на добавленную стоимость распределяемого в доходы местных бюджетов; снижение ставок налога на имущество; отмена налоговых скидок; предоставление местным органам власти определенных налоговых полномочий, включая возможность изменять налоговое законодательство и корректировать налоговые ставки. Указывается, что при реформировании межбюджетных отношений необходимо обеспечить стабильность фискальной системы, чтобы усилить ее стимулирующую и регулирующую роль

\section{КЛЮЧЕВЫЕ СЛОВА}

Фискальный менеджмент, межбюджетные отношения, фискальная система, распределение налоговых доходов

\section{ОСНОВНЫЕ ПОЛОЖЕНИЯ}

1. В Китае должна быть создана система фискального управления соответствующая современной фискальной системе страны и продолжена стандартизация распределения административных и расходных полномочий различных уровней власти

2. Система межбюджетных трансфертов в Китае должна быть формализована, а иерархическая система финансового управления должна включать распределение между бюджетами налогов, арендной платой и прибылью

\section{Introduction}

The Third Plenary Session of the $18^{\text {th }}$ CPC Central Committee in 2013 set the goal of China's fiscal reform to establish a modern fiscal system. "Establishing a system whereby authority of office matches responsibility of expenditure" is one of the three major priorities. On June 30, 2014, the Political Bureau of the CPC Central Committee deliberated and adopted the Plan for Deepening Overall Reform of the Fiscal and Tax Systems, which calls for adjustments to local-central fiscal relations. Specifically, the reform should rationalize the allocation of local-central fiscal revenues in line with expenditure responsibilities.

The recognition of the importance of a well-designed and comprehensive system of intergovernmental fiscal relations has the deep roots in the local government economics and fiscal decentralisation liter- ature [1-7]. There are numerous academic research in the field of fiscal decentralization in China which reflect the processes, characteristics, and measurements of fiscal decentralization. See for example [8-11].

In adjusting local-central fiscal relations, the ultimate goal is to create a hierarchical fiscal management system [12-14]. China's tax sharing reform in 1994 laid out the basic framework for today's local-central fiscal relations and was carried out in tandem with tax reform and the creation of a tax collection and management system. Over the past two decades, China's fiscal prowess grew to strength steadily, with fiscal revenue as a percentage in GDP up from around $10 \%$ to $22.5 \%$ in $2015^{1}$. Strong fiscal resources

${ }^{1}$ According to the final accounts of national general public budget revenue, in 2015, China's fiscal revenue amounted to 15.223 trillion yuan and GDP totaled 67.67 trillion yuan. 
empowered government regulation in a market-based economy. Nevertheless, the legacy problems under this system must be addressed through further reforms ${ }^{2}$.

\section{Problems of local-central fiscal relations}

Negative incentives from alignment between fiscal revenues and administrative authority. Before 1994, local-central fiscal relations were subject to the principle of alignment between fiscal power and administrative authority. Under this principle, prosperous regions were incentivized to make most of local fiscal resources. However, in less developed regions, it was difficult for local governments to collect sufficient revenues to finance a wide range of public services. To address this dilemma, the Report of the $17^{\text {th }}$ CPC National Congress called for "improving the fiscal and taxation systems so that the financial resources of governments are in line with their respective responsibilities" in 2007. By matching fiscal revenues with expenditure responsibilities, the central government ensured adequate fiscal resources for less developed regions, particularly counties and townships. However, due to their unfavorable position in revenue allocation under the new system, prosperous regions were not fully incentivized to explore local fiscal resources essential to the provision of public services.

Negative Incentives from the Uncertainty of Revenue Sharing. Policy stability is the foundation for hierarchical fiscal management system. In 1994, personal income tax was a local tax. After the income tax sharing reform in 2002, personal income tax and corporate income tax became shared taxes between local and central governments. The progress is that for many enterprises, payment of income tax is no longer subject to their administrative affiliation to the central or local government. However, a few SOEs under the central government are exempted from the sharing of income tax. Furthermore,

\footnotetext{
${ }^{2}$ Some papers such as the paper by Lou Jiwei also reflected China's intergovernmental fiscal relations, but the choice of reform options in this paper is much different by comparison [15].
}

the sharing of income tax is subject to a fixed base. In this sense, reform of the shared corporate income tax is incomplete. Personal income tax, which would be otherwise a central tax and whose amount of revenue was limited, was left to local governments. After personal income tax developed into a major source of tax revenue, turning it into a shared tax inevitably dampened local enthusiasm for tax collection. Business tax, which used to be the most important source of revenue for local governments, is integrated into value-added tax (VAT) with the implementation of the reform of replacing business tax with VAT. Although VAT revenues are shared evenly between central and local governments, the reform took a toll on local fiscal resources. As a result, the central government returned a surplus of 178 billion yuan to local governments to ease local fiscal gaps in 2016. However, the uncertainties of local fiscal resources inevitably affected the behavior of local governments.

Negative incentives from imperfect tax rebate and transfer payment system. China's fiscal reform of 1994 determined the ratio of central-local fiscal revenue to be $6: 4$, the ratio of central-local fiscal expenditure to be $4: 6$, and the return of $20 \%$ fiscal revenues from central to local governments. This target has never been achieved. A major proportion of local general public budgetary expenditure has been funded by the central government. Despite a slight decrease in recent years, the tax rebate and transfer payment made by the central government to local governments amounted to 5509.751 billion yuan, accounting for $36.65 \%$ of the 15.03 trillion yuan local general public budgetary expenditure $^{3}$. Tremendous tax rebates and transfer payments led to inefficiencies and overreliance on the central government.

The unreasonable structure of transfer payments also posed a challenge to the creation of a hierarchical fiscal system. In

${ }^{3}$ Such data and the fiscal data of 2015 in the following paragraph are from "National Fiscal Final Accounts" formulated by the Ministry of Finance (Available at: http://yss.mof.gov. cn/2015js/index.html). 
2015, central-local tax rebates amounted to 501.886 billion yuan, general transfer payments reached 2845.502 billion yuan, and special transfer payments totaled 2162.363 billion yuan, accounting for $9.11 \%, 51.64 \%$ and $39.25 \%$ respectively of the total amount of tax rebates and transfer payments. Initially intended as a temporary arrangement, tax rebates lasted for more than 20 years. General transfer payments, which account for more than $50 \%$ of the total, have many characteristics of special transfer payments. Many items of general transfer payments are associated with specific policy objectives, including transfer payments for remote and less developed regions, tax reform for finished oil products, grassroots public security funding, basic pension, as well as medical insurance.

Many items of balancing transfer payment that have nothing to do with specific local policy objectives also have the nature of special transfer payments. For instance, transfer payments are made to assist ecological function areas, grain-producing counties, county-level basic fiscal security, resource-depleted cities, urban and rural compulsory education, and integrated rural reform. A few items of transfer payments (such as intergovernmental settlement allowance) are legacies of an obsolete system. Due to the lack of transparency in decision-making, the special transfer payment system is also under a great deal of criticism and needs further reform.

Interplay with other systems threatens socio-economic sustainability. Intergovernmental fiscal relations are the weathervane of China's socio-economic development. This system laid the foundation for China's socio-economic development over the past two decades. In the meantime, the relative central-local fiscal power changed as well. Compounded by other systems, the inherent defect of this system poses grave challenges to sustainable socio-economic development in the future. Local governments have an insatiable demand for revenues to keep up with growing expenditures. Their ownership of land means that revenues can be earned from selling land to real estate developers. Thanks to China's booming housing market, land sales revenues account for staggering proportions of local government coffers. However, reliance of fiscal revenue on the sales of governmentowned land is unsustainable. Further, it inflates property prices and distorts the ratio of house price to income. The inherent factor of instability in China's real estate market threatens socio-economic sustainability.

\section{Standardize assignment of administrative authority vis-a-vis expenditure responsibilities}

Assignment of administrative authority must be stable and adjusted on a dynamic basis. Proper assignment of administrative authority vis-a-vis expenditure responsibilities requires the government to transform its functions, which is an ongoing process. So far, progress has already been made in this area and the concept of streamlining government administration and delegating power is well received. Assignment of administrative authority vis-a-vis expenditure responsibilities should be adjusted on a dynamic basis in sync with this process and changing realities. With the wax and wane of industries and technologies and the dynamics of social progress, demand for public services keeps changing and must be reflected in the assignment of administrative authority and expenditure responsibilities. New public services and affairs, which are complicated and take time to discern, must be classified into different categories of administrative authority for different levels of government.

Assignment of administrative authority and expenditure responsibilities is not just a fiscal issue. It relates to the reform of the administrative and even the political system. At the fundamental level, this important matter must only be resolved by law. In the past, regions with fast-growing or strong fiscal revenues were tasked with additional administrative responsibilities, which is justified yet caused negative incentives at the local level. Legislation is the most powerful instrument to ensure the stable and predictable assignment of 
administrative authority and expenditure responsibilities. Despite adaptability to changing social conditions, the hierarchy of the current legislation is insufficient to guarantee such stability and predictability. Thus, conditions must be created to formalize the assignment of administrative authority and expenditure responsibilities by law at a higher hierarchy to reduce artificial adjustments. An ideal approach is to formalize the assignment of administrative authority and expenditure responsibilities in line with the Constitution. China must accelerate its development of the rule of law to ensure such stability and predictability.

Common administrative authority needs to be further specified. The assignment of administrative authority and expenditure responsibilities is a systematic project. The Guiding Opinions of the State Council on Reforming Central-Local Fiscal Authority and Expenditure Responsibilities released in August 2016 marks a good beginning but still focuses on the assignment of "fiscal administrative authority". Based on whether or not the government invests, administrative authority can be categorized into fiscal authority and nonfiscal authority. For most undertakings, the government should mobilize private resources rather than devote its own financial resources. According to the Opinions, China should create more common fiscal responsibilities compared with sophisticated market economies. However, the overlap of central-local responsibilities contributes to confusion and evasion of responsibilities. While such overlap is unavoidable, the key is to create incentives to maximize the enthusiasm of both central and local governments.

For instance, local governments in some western regions in China that suffer a brain drain argue that compulsory education should be funded by the central government. But actually compulsory education has a strong positive spillover effect that also brings about local benefits. Compulsory education promotes the equalization of local income distribution, social benefits and local welfare. In addition, given their understanding of local realities, it is more appropriate for local governments to provide compulsory education services. This is why a special premium is put on local responsibilities when it comes to compulsory education in major countries across the world. It is not easy to define the fiscal authority and expenditure responsibilities of the central government. Nevertheless, arguments over this question cannot diminish the importance of compulsory education.

Another prominent question is basic pension services. In reality, some local governments have already encountered difficulties of basic pension payment. Yet diverting pension resources across regions may cause more regions to experience pension payment difficulties. Under the current system, local governments should try to overcome the difficulties on their own before resorting to central fiscal assistance. Given China's unified labor market, a basic pension system requires national pooling. Yet such pooling should put more emphasis on central government responsibilities. A reasonable approach is to divert fiscal resources from elsewhere to help localities with basic pension payment difficulties. Nevertheless, it is by no means easy for central and local governments to determine their respective responsibilities on basic pension security.

Respect the role of local government initiative. Incentives must be created for local governments in reforming the assignment of administrative authority and expenditure responsibilities. The key is to bring local initiative into play.

Given China's reality, it is justified for the central government to determine fiscal authority and the assignment of centrallocal fiscal powers. However, arrangements must be in place to incentivize local governments. Legislation should take into full account the role of local governments. The central government must collect feedback from localities before making a decision. Given the great regional differences in China, systems inconsistent with local realities will not work. Legislation must respect local situations to achieve the expected outcome. 
Performance of administrative authority at the local level must be assured by fiscal power and resources. It is challenging yet necessary for local governments to provide a wide range of public services. In a transition society fraught with contradictions, public security concerns and other problems are not caused by a particular locality in isolation. Local authorities must be empowered with the necessary fiscal power and resources in order to perform their responsibilities. It is also challenging to ensure that localities with different conditions are endowed with sufficient fiscal power and resources under a unitary system. It is important that administrative authority and expenditure responsibilities be divided clearly between central and provincial governments to make it easier for the rights and responsibilities to be assigned to localities below the provincial level. In making this assignment, the "one-size-fits-all" approach must be avoided. Localities should be encouraged to explore systems consistent with their realities.

\section{Standardize government revenue allocation}

Create a comprehensive payment and revenue allocation system. In 1994, the allocation of fiscal revenues mainly involved taxation. Yet under integrity considerations, the scope of revenue allocation should also include the rent income of state-owned resources, revenues from state-owned land, government funds, profits from the operation of state-owned capital, etc. For revenues not included under the framework of the tax sharing reform in 1994, any attempt to share them will be inevitably resisted by their existing owners. In overcoming vested interests, China must expedite government reforms and make government budget and final accounts even more transparent. Similar to taxation, the threshold for creating administrative fees and government funds must be raised substantially. The ultimate goal is to create a system of government revenue allocations encompassing taxation, rents and profits.
Given the lion's share of taxation in government revenue, the key to revenue allocation is to form a reasonable local tax system. Currently, local fiscal expenditures are primarily funded by local tax revenues. Hence, central tax and shared tax should be the priorities for the reform of government revenue allocation.

Increased share of local governments in VAT distribution is justified. With the pilot implementation of the reform of replacing business tax with VAT, VAT revenues are distributed equally between central and local governments. An increased share of VAT distribution is justified because it will compensate for the reduction of local revenues after tax system standardization and strengthen local fiscal resources. Some argue that a higher share in VAT distribution will induce misconduct by local governments. This paper believes that this view is unfounded. First, the equal distribution of VAT revenues is a temporary measure to make up for local fiscal deficiency without business tax. Adequate tax revenues are essential for local governments to function properly. Second, the so-called misconduct has more to do with market distortions caused by government, which should be addressed by rationalizing the relationship between government and market. A higher share in revenue distribution in favor of local governments will not lead to misconduct as long as proper relations with the market are formalized.

Revamp consumption tax into a central-local shared tax. Under the current system, consumption tax is, in theory, a central tax. Yet in reality, consumption tax revenues are subject to rebate and not purely a central tax. After the tax-for-fee reform for finished oil products, the majority of consumption tax converted from road toll is returned to local governments and the nature of consumption tax as a shared tax became evident. The tax sharing scheme can be designed according to the types or total revenues of consumption tax. While the former caters to different types of local taxation, the latter corresponds to the overall adjustment of fiscal power and resources. Currently, 
consumption tax is primarily levied on manufacturing and wholesale activities. This paper suggests that consumption tax also be levied on retail business and defined as local tax revenue, thus incentivizing local governments to encourage consumption. The question is the feasibility of collecting consumption tax from retail business. Considering the significant share of tobacco and alcohol in consumption tax, revenue disparities may expand across regions and not all regions may benefit. But if this plan is adopted, the share of VAT for local governments can be somewhat reduced.

Reform of property tax and land revenue system. Foreseeably, the significance of property tax to local tax revenue will continue to rise. The imposition of property tax on households is intended to move the tax burden from purchase to possession. In China, the possession of real property is almost tax-free. Yet homeowners have to pay various taxes and fees for the development and purchase of commercial housing. Increasing the tax burden on the possession of real property will only aggravate their tax misery and reduce public welfare ${ }^{4}$. Compared with countries of private land ownership, the property tax rates should be much lower in China. In addition, in view of China's skyrocketing housing prices, households may not be able to afford to pay property tax even if it is introduced ${ }^{5}$.

Local Governments should be endowed with certain taxing authority, including legislation and tax rate adjustment. There are some misperceptions about the concept of unitary states. In fact, the tendencies of centralization and decentralization of power for unitary and federalist states have been constantly changing. While unitary states decentralize, federalist states centralize. The argument that unitary states cannot decentralize taxing authority is unfounded. Indeed,

${ }^{4}$ Car parking charges in cities may also become a major source of revenue for local governments.

${ }^{5}$ This is also the reason why property tax cannot become a major source of local tax revenues in China in the short term. in some small unitary states, local tax revenues account for a minor share. However, this cannot be used as the basis to argue against the creation and improvement of China's local tax system. As a large country, China's optimal intergovernmental fiscal relations must be fine-tuned and optimized on a constant basis. Once property tax is fully rolled out, unless local governments have the authority to adjust the tax rates, their efforts to improve public services may lead to housing price hikes and a higher property tax burden for households ${ }^{6}$. Of course, granting certain taxing authority to local governments does not inhibit formation of a unified national market.

Standardization of government revenue allocation naturally involves the issue of debt financing. Local government financing involves particularly complicated questions. In general, local government expenditure must be funded by tax revenues rather than debts. The debt issuing authority of local governments under a hierarchical fiscal system does not mean that liabilities can be a major source of local fiscal resources ${ }^{7}$. Unchecked financing from public property rights will jeopardize local government sustainability. In fact, financing from public property rights is to blame for China's addiction to land sales. From the perspective of socioeconomic sustainability, financing from public property rights must be conducted with great caution.

\section{Standardization of fiscal transfer payment}

Cancel tax rebates. Undeniably, tax rebates played a positive role in facilitat-

${ }^{6}$ For instance, after a subway line is put into operation, adjacent land value will increase. However, if local governments are not able to adjust the tax rates, the burden of property tax for homeowners will rise as well. As a result, the subway that is intended to improve people's welfare actually increases their burden. If the tax power is attributed to local governments, tax rates can be lowered at the local level to ease the increased tax burden in case housing prices increase.

7 Tremendous local liabilities must be resolved through special one-time solutions and will not be elaborated on in this paper. 
ing China's tax sharing reform. Without tax rebates, it was impossible for the tax sharing reform to be carried out in the first place. However, while creating incentives for prosperous regions, tax rebates caused a massive flow of funds to developed regions, widened regional fiscal disparities and compromised the equalization of public services. Tax rebates have been in existence for more than two decades and transfer payments have yet to standardize. Obsolete arrangements such as tax rebates and revenues submission (allowance) need to be phased out. Despite the declining share of tax rebates in the transfer payment system, their absolute size remains significant. China must phase out tax rebates to enhance the tax sharing system. To avoid causing major impacts to local fiscal power, tax rebates should be reorganized into general transfer payments.

Create an integrated vertical and horizontal transfer payment system. Transfer payments include various patterns such as vertical, horizontal and hybrid transfer payments. Under the vertical model, transfer payments take place between central and local governments. Under the horizontal model, they take place between local governments. A hybrid model features both characteristics. China currently practices a vertical transfer payment system.

Partner assistance exists across various parts of China. Partner assistance and economic cooperation are some of the key features of China's institutional advantage. They promote socio-economic development in less developed regions through targeted assistance. In China, 19 provinces and municipalities are involved in partner assistance to Xinjiang Uygur Autonomous Region; 17 provinces and municipalities are involved in partner assistance to Tibet Autonomous Region. For instance, Beijing provides partner assistance to Xinjiang, Tibet, Qinghai, Badong County of Hubei Province, and Shifang City of Sichuan Province. In addition, other partner assistance programs also exist, including assistance to Qinghai.

Regional cooperation and relief may also take the form of economic coopera- tion. Regional cooperation schemes include Beijing-Tianjin, Beijing-Hebei, Beijing-Shanxi and Beijing-Inner Mongolia cooperation. Relief and coordination programs include Chifeng and Ulanqab assistance programs and south-north water diversion project coordination ${ }^{8}$.

Partner assistance and economic cooperation must be supported by sufficient fiscal funds. Supporting regions have to use local fiscal resources to assist less developed regions. This system is actually a horizontal transfer payment system and must be formalized. For recipient regions, coordination with the vertical transfer system is also an issue. Optimizing the vertical transfer system also requires a proper linkage between partner assistance and economic cooperation.

In providing partner assistance using local fiscal resources, local governments actually perform the responsibility of public service equalization, which otherwise should be assumed by the central government. Hence, horizontal and vertical transfer payment systems should be brought into overall consideration. Theoretically speaking, the objectives of horizontal transfer payments may also be achieved through vertical transfer payments. However, horizontal transfer payments must be formalized in order to increase the efficiency and scale of assistance.

In vertical transfer payments, this paper suggests that funds be allocated directly to county governments to alleviate the dearth of fiscal resources at the grassroots level. The amount of vertical transfer payments should be determined according to the number and size of central government projects at the local level. These projects will boost local fiscal resources. Their effect on local economic growth needs to be further evaluated.

Reduce the scale of transfer payments. Central government boasts the advantage of economies of scale in raising fiscal revenues. For many local governments, their fiscal revenues are dwarfed by expenditure and must be supplement-

\footnotetext{
${ }^{8}$ See Beijing Partner Assistance and Economic Cooperation Network (Available at: http:// www.bjzyhzb.cn/dkzy/ybgz/).
} 
ed by transfer payments. Through transfer payments, the central government may also enhance its control on local governments. Given the various costs of fiscal fund transfer, a desirable approach is to reduce the scale of transfer payments as much as possible.

The magnitude of transfer payments is subject to many factors. While current transfer payments aim to satisfy public budget, the amount of future transfer payments must be determined in light of other fiscal resources at the disposal of government. In determining the size of transfer payments, one question must be properly addressed: Should China adopt a centralized transfer payment system or a decentralized one? While centralized transfer payments afford the central government enhanced regulatory capacity, they do not help in increasing the enthusiasm of local governments. The opposite is true for a decentralized transfer payment system. In addition, a significant amount of transfer payments is more likely to be mobilized under a centralized system than a decentralized one. There might be a certain extent of equivalence in the choice of centralized, decentralized or hybrid transfer payment systems but the key is to identify a system of compatible incentives.

Reshape general and special transfer payments. General transfer payments are determined by estimating the gap between standard income and standard expenditure with consideration of the fiscal resources factor. General transfer payments entail certain negative incentives and currently only apply to balancing transfer payments. Therefore, the general transfer payment system must be improved by incorporating more incentives in the estimation of standard income and take into account more fiscal endeavors to reduce the negative impacts.

Special transfer payments have clear payment policy objectives but the decision-making process should be open and transparent. In addition, a certain extent of competition should be introduced. There are many pathways to achieve policy objectives. Conditions must be created for local governments to compete for such funds to minimize the cost for achieving policy targets.

General transfer payments are, at the very least, no less efficient than special transfer payments. In this sense, special transfer payments should be reduced as much as possible. Provided that local governments are able to allocate transfer payment funds, general transfer payments would be more advisable. If the objective of the central government is to raise the level of a certain type of public service nationwide, special transfer payments would be more appropriate. The level of local government budget restraint also affects the choice of transfer payment method. Insufficient restraint may cause the funds to be allocated to inefficient projects, thus affecting the achievement of transfer payment objectives.

Special transfer payments may address many problems that cannot be addressed by general transfer payments, particularly the improvement of certain basic public services such as compulsory education and health care. Transfer payments should also be determined according to the different positioning of main function zones with corresponding standard income and expenditure. With environmental restoration and maintenance responsibilities, regions restricted or prohibited for development must pay a higher price of environmental protection for the development of main function zones.

China's special transfer payment items are complicated, myriad and overlapping. Use of funds is scattered and some projects are designed in disregard of local realities. These items must be classified and rearranged for better management to serve the role that cannot be played by other forms of transfer payments in the improvement of basic public services.

Existing central fiscal transfer payments excessively require local matching funds. As a result, some localities that cannot provide sufficient matching funds fail to receive transfer payments despite their desperate need for support. Sometimes, these localities are forced to resort to data fraud, which affects the achievement of objectives for special transfer payments. 
Hence, the requirement of local matching funds must be abandoned in some circumstances.

As local fiscal management is governed by more restraint in the future, special transfer payments can be downsized. China's current tax rebate and balancing transfer payments fall in the category of unconditional transfer payments. In the future, these different forms of transfer payments must be integrated to fashion a unified general transfer payment system where the amount of transfer payments is determined according to the difference between local income and expenditure.

Create a standardized fiscal transfer payment system. So far, intergovernmental transfer payments in China are not formalized and often conducted through various "circulars" and "decisions" of the central government. This affects not only the formation of reasonable expectations at the local level but the standardization of intergovernmental fiscal relations as well.
Currently, the creation of an institutional framework for China's transfer payments must be backed by legislation and long-term strategic planning to make transfer payments predictable. A timetable for reform should be specified to create stable expectations for local governments. For instance, the amount of transfer payments should be adjusted with an interval of five years. Explicit requirements are much more positive than ad hoc regulations.

China may also consider establishing an intergovernmental transfer payment council to increase the transparency of central fiscal transfer payments, incentivize local governments, and properly balance central-local fiscal relations. The council should be responsible for evaluating the transfer payment plan submitted by the central fiscal appropriation expert committee and submit the plan to China's legislature for review and approval.

\section{References}

1. Musgrave R. A. The Theory of Public Finance: A Study in Political Economy. New York, McGraw-Hill, 1959.

2. Bahl R. Implementation Rules for Fiscal Decentralisation, Atlanta, Georgia USA, Georgia State University, 1999.

3. Bailey S. Local Government Economics: Principles and Practice. London, Macmillan Press, 1999.

4. Ter-Minassian T. (ed.). Fiscal Federalism in Theory and Practice. Washington, D.C.: IMF, 1997.

5. Ahmad E., Brosio G. (eds.) Handbook of Fiscal Federalism. Cheltenham, UK: Edward Elgar, 2006.

6. Bird R. M., Vaillancourt F. (eds.). Perspectives on Fiscal Federalism. Washington D.C.: The World Bank, 2006.

7. Charbit C. Explaining the Sub-National Tax-Grants Balance in OECD. Countries. OECD Working Papers on Fiscal Federalism. Paris, OECD, 2010, no. 11.32 p. DOI: 10.1787/5k97b10s1lq4-en.

8. Jin Jing, Heng-fu Zou. Soft Budget Constraints and Local Government in China. In Rodden J. A., Eskeland G. S., Litvack J. I. (eds) Fiscal Decentralization and the Challenge of Hard Budget Constraints. Cambridge, MA: MIT Press, 2003, pp. 289-322.

9. Wong C., Bird R. M. China's Fiscal System: A Work in Progress. In Brandt, Rawski (eds) China's Great Economic Transformation. Cambridge, Cambridge University Press, 2008.

10. Shen Chunli, Jing Jin, Heng-fu Zou. Fiscal Decentralization in China: History, Impact, Challenges and Next Steps. Annals of Economics and Finance, 2012, vol. 13, no. 1, pp. 1-51.

11. Wang Z., Ma L. Fiscal Decentralization in China: A Literature Review. Annals of Economics and Finance, 2014, Vol. 15, no. 2, pp. 751-770.

12. Yang Zhiyong. How the Reform of Tax Assignment Begins in China. Sub National Fiscal Research, 2013, no. 10.

13. Yang Zhiyong. A Study on the Division of Responsibilities between the Central and Local Governments in the Reform of Tax Assignment in China. Comparative Economic \& Social Systems, 2015, no. 2.

14. Yang Zhiyong. Study on Change of Thought of Power Division between Central and Local Governments: Historical and Comparative Approaches. Public Finance Research, 2016, no. 9.

15. Lou Jiwei. Rethinking of Intergovernment Fiscal Relations in China. Beijing, China Financial and Economic Publishing House, 2013. 


\section{Author}

Yang Zhiyong - PhD in Economics, Professor, Associate Editor of Financial Minds Editorial Department, National Academy of Economic Strategy of Chinese Academy of Social Sciences (CASS) Beijing, China (F 12, Zhongye Plaza No. 28, Shuguang Xili, Chaoyang District, 100028) e-mail: zyyang@cass.org.cn

\section{Информация об авторах}

Ян Чжиюн - доктор экономических наук, профессор, редактор отдела финансов редакции, Национальная академия экономической стратегии Китайской академии социальных наук, г. Пекин, Китай (100028, Китай, г. Пекин, Район Чаоянг, ул. Шугуан Хили, 28, строение Зонгуе, этаж 9); e-mail: zyyang@cass.org.cn

\section{For citation}

Yang Zhiyong. Local-central Intergovernmental Fiscal Relations of China. Journal of Tax Reform, 2017, vol. 3, no. 2, pp. 92-102. DOI: 10.15826/jtr.2017.3.2.033

\section{Аия цитирования}

Ян Чжиюн. Проблемы медбюджетных отношений центрального и местного уровней власти в Китае / Ян Чжиюн // Journal of Tax Reform. - 2017. - Т. 3, № 2. - C. 92-102. - DOI: $\underline{10.15826 / \text { itr.2017.3.2.033 }}$

\section{Article info}

Received April 10, 2017; accepted July 31, 2017

\section{Информация о статье}

Дата поступления 10 апреля 2017 г.; дата принятия к печати 31 июня 2017 г. 